\title{
Measles outbreak investigation in Artuma Fursi Woreda, Oromia Zone, Amhara Region, Ethiopia, 2018: a case control study
}

\author{
Mengistie Kassahun Tariku ${ }^{* *}$ and Sewnet Wongiel Misikir ${ }^{2}$
}

\begin{abstract}
Objective: To confirm the existence of Outbreak, describe cases in person, place and time, and identify determinants of the outbreak. Unmatched case control study in the ratio of 1:4 (38 cases and 152 controls) was conducted in Artuma Fursi Woreda from July 13 to August 1/2018. Data were collected with standard questionnaires. Collected data were entered into Epi Info version 7 and exported to Statistical package for social science (SPSS) version 23 for analysis.

Results: A total of 38 cases and 1 death with attack rate and case fatality rate 11.8/100,000 and 2.6\%, respectively. All study participants had not vaccination history. Females and age group 5-14 were more affected. Being 5-14 years old versus $(v s) \geq 15$ years [adjusted odd ratio $(A O R)=3.53 ; 95 \% \mathrm{Cl} 1.52-8.45)$ ], contact with cases vs no contact with cases $[\mathrm{AOR}=2.78 ; 95 \% \mathrm{Cl} 1.23-8.67]$ and travel history $7-18$ days prior onset of illness vs no travel history $[\mathrm{AOR}=2.53 ; 95 \%$ Cl 1.31-7.24] were significantly associated with contracting measles. Routine and supplement immunization should be strengthened to reduce future occurrence of outbreak.
\end{abstract}

Keywords: Measles, Outbreak, Artuma Fursi Woreda

\section{Introduction}

Measles is a highly contagious, serious disease caused by a virus $[1,2]$. Any person with fever, and non-vesicular rash, and cough, runny nose or red eyes is the suspect of measles case. Confirmed measles case is a suspected case with laboratory confirmation (positive for immunoglobulin $\mathrm{M}(\operatorname{IgM})$ antibody) [3]. Measles is caused by a virus in the paramyxovirus family and it is normally passed through direct contact and through the air. The virus infects the respiratory tract, and then spreads throughout the body. Measles is a human disease and is not known to occur in animals [4].

Before the introduction of measles vaccine in 1963 and widespread vaccination, major epidemics occurred approximately every $2-3$ years and measles caused an estimated 2.6 million deaths each year $[1,2]$.

\footnotetext{
*Correspondence: mengesh2009@gmail.com

${ }^{1}$ Aneded Woreda Health Office, East Gojjam, Amhara Region, Ethiopia

Full list of author information is available at the end of the article
}

The disease remains one of the leading causes of death among young children globally, despite the availability of a safe and effective vaccine $[1,5]$. Approximately 89 780 people died from measles in 2016-mostly children under the age of 5 years [1].

In populations with high levels of malnutrition, particularly vitamin A deficiency, and a lack of adequate health care, about $3-6 \%$, of measles cases result in death, and in displaced groups, up to $30 \%$ of cases result in death. Women infected while pregnant are also at risk of severe complications and the pregnancy may end in miscarriage or preterm delivery. People who recover from measles are immune for the rest of their lives $[4,6]$.

The case fatality rate of measles disease was increased with travel distance from the nearest health facility. The difference in the access to health care can affect the burden of the disease in low-income settings [7].

In countries with weakly functioning health care systems, measles mortality reduction or elimination was addressed through second dose periodic supplementary immunization activities (SIAs) in the form of mass 
campaigns. Strengthen routine vaccination service can improve measles control, measles death reduction and elimination program which can help build up primary health care capacity [8].

Measles has been difficult to eliminate historically, but there is a global goal to eradicate it, and measles was first eliminated in the Americas [9].

In Ethiopia, implementation of measles death reduction approach was launched in 2002. The national Expanded Program on Immunization was started in 1980, and the first dose of measles-containing vaccine (MCV1) is given at or after the ninth month of age [10]. About $54 \%$ of 12-23 months children were received routine measles vaccination in 2016 [11]. Supplementary immunization activities were conducted every 2 to 4 years, targeting all children between 9 months and 14 years of age [12].

Suspected measles outbreak is defined as occurrence of five or more reported suspected cases in 1 month in a defined geographic area, like, Kebele (the smallest administrative unit of the Woreda in Ethiopia), district or health facility catchment area whereas Confirmed measles outbreak is defined as occurrence of three or more laboratory confirmed cases in 1 month in a defined geographic area, like, Kebele, district or health facility catchment area [3].

Measles outbreaks can occur in areas with high vaccination coverage [13]. It is also common in many lowincome countries but there is limited information in confirming the outbreak, describing the outbreak in terms of person, please and time, and identifying determinants of outbreak [14].

Measles is one of immediately reportable disease in Ethiopia. On Wednesday morning, July 12/2018, one Suspected measles case was reported from Golbo Arba Kebele in Artuma Fursi Woreda. Within 2 h, three field Epidemiology residents and one Artuma Fursi Woreda health office Public health Emergency officer visited the reported Kebele to confirm the existence of the outbreak, describe cases in person, place and time, and identify determinants of measles case status.

\section{Main text \\ Methods \\ Study setting and period}

Unmatched case-control study design was done from July 13-Agust 1/2018 in Golbo Arba Kebele, Artuma Fursi Woreda, Oromia Zone, Amhara Region, Ethiopia. The Woreda is located about $305 \mathrm{~km}$ from Addis Ababa (the capital city of Ethiopia) and $575 \mathrm{~km}$ from Bahir Dar. The area of the Woreda is $782.22 \mathrm{~km}^{2}$ with the total population 103,611. The Woreda is administratively divided into 25 kebeles. There are 6 health centers and 25 health post in the Woreda. Golbo Arba Kebele has total population of 3229 [15].

\section{Sampling size and sampling technique}

The sample size was calculated in Epi Info version 7. Our sample size was designed to determine significance of the relationship between vaccination and case status. Based on an alpha value of 0.05 , and a predicted prevalence of non-vaccination of $31 \%$ among controls and $86.2 \%$ among cases [16], we would need 38 cases enrolled in the study. However, due to missing data with the vaccination variable, we did not include it in the final multivariable analysis. We ended up enrolling all measles cases in the area in the study period, and sampled cases to controls based on the 1:4 ratio to increase efficiency of results. All eligible cases [any person with fever and maculopapular (non-vesicular) generalized rash and cough, Coryza or conjunctivitis (red eyes)] were included in the study whereas all eligible controls (neighbors or family member of cases who did not have fever, non-vesicular generalized rash and cough) were selected by lottery method simple random sampling. Both cases and controls who had history of measles in the previous years were excluded.

\section{Measurement}

The data were collected from house-to-house search for measles case. A standard questionnaire was used to collect data using face to face interview technique by 3 Field Epidemiology residents. Serum specimens were collected from five suspected measles cases and sent to the national measles laboratory for IgM test and a test done as per the global and national guidelines.

\section{Data analysis}

Data were coded and entered using Epi-Info 7 and analyzed by SPSS version 23. Data cleaning and recoding was preformed, then descriptive, bivariate and multivariable binary logistic regression was done. Bivariate analysis was computed. Each variable that has $p$-value $\leq 0.25$ was entered into multivariable analysis. In multivariable analysis, every variable that has p-value $<0.05$ was considered significance. Results were presented using text, tables and graphs.

\section{Result}

\section{Descriptive epidemiology}

A total of 38 measles cases, 1 death and 152 controls and that fulfill standard case definition were identified. The median age of the cases was 7.5 years [interquartile range $(\mathrm{IQR})=9.25$ years] and for that of the controls was 25 years $[\mathrm{IQR}=17$ years]. In this investigation, higher attack rate [(AR) 139.4/10,000] was reported among females. Case fatality rate $(4.3 \%)$ was also higher among 
females. Higher AR $(291.0 / 10,000)$ was reported among age group 5-14 years. Case fatality rate (4\%) was also higher among age group 5-14 years.

More than half, 23 (57.1\%), of cases and 81 (53.3\%), of controls were female. Regarding to educational status of mothers/care givers, 27 (71.1\%) of mothers/care givers of cases and 102 (67.1\%) of mothers/care givers of controls were unable to read and write (Table 1 ).

Distribution of cases by place: In this outbreak, all measles cases were from one gote.

Distribution cases by Time: The index case showed sign and symptom on $7 / 12 / 2018$. The index case had travel history to chefa Robite and had history of contact with person who came from Saudarbia who had similar sign and symptom. More than one-fourth, 10 (26.3\%) of cases

Table 1 Socio demographic characteristics of Study participant in Artuma Fursi Woreda, Oromia Zone, Northeast Ethiopia, 2018

\begin{tabular}{|c|c|c|}
\hline \multirow[t]{2}{*}{ Variables } & \multicolumn{2}{|c|}{ Respondent status } \\
\hline & $\begin{array}{l}\text { Cases } \\
(\mathrm{n}=38), \mathrm{N} \\
(\%)\end{array}$ & $\begin{array}{l}\text { Controls } \\
(n=152), N \\
(\%)\end{array}$ \\
\hline \multicolumn{3}{|l|}{ Sex } \\
\hline Female & $23(57.1)$ & $81(53.3)$ \\
\hline Male & $15(42.9)$ & $71(46.7)$ \\
\hline \multicolumn{3}{|l|}{ Age in year } \\
\hline$<1$ & $2(5.3)$ & $8(5.3)$ \\
\hline $1-4$ & $10(26.3)$ & $12(7.9)$ \\
\hline $5-14$ & $24(63.2)$ & $53(34.9)$ \\
\hline$\geq 15$ & $2(5.3)$ & $79(52.0)$ \\
\hline \multicolumn{3}{|l|}{ Educational status of study participants } \\
\hline Not eligible & $12(31.6)$ & $20(13.2)$ \\
\hline Unable to read and write & $19(50.0)$ & $52(34.2)$ \\
\hline $\begin{array}{l}\text { Read and write but have no formal educa- } \\
\text { tion }\end{array}$ & $5(13.1)$ & $27(17.8)$ \\
\hline Primary & $2(5.3)$ & $53(34.9)$ \\
\hline \multicolumn{3}{|l|}{ Educational status of mothers/care givers } \\
\hline Unable to read and write & $27(71.1)$ & $102(67.1)$ \\
\hline $\begin{array}{l}\text { Read and write but have no formal educa- } \\
\text { tion }\end{array}$ & $8(21.0)$ & $32(21.1)$ \\
\hline Primary & $3(7.9)$ & $18(11.8)$ \\
\hline \multicolumn{3}{|l|}{ Do measles have medical treatment } \\
\hline No & $27(71.1)$ & $91(59.9)$ \\
\hline Yes & $11(28.9)$ & $61(40.1)$ \\
\hline \multicolumn{3}{|l|}{ Contact with case } \\
\hline No & $32(84.2)$ & $111(73.0)$ \\
\hline Yes & $6(15.8)$ & $41(27.0)$ \\
\hline \multicolumn{3}{|l|}{ History travel 7-18 days prior onset of illness } \\
\hline Yes & 15 (39.5) & $36(23.7)$ \\
\hline No & $23(60.5)$ & $116(76.3)$ \\
\hline
\end{tabular}

had onset of symptom on July $23 / 2018$ and July $26 / 2018$ (Fig. 1).

Laboratory investigation: Among the total samples, 3 $(60 \%)$ of samples were IgM positive for measles. Other remaining cases were confirmed by epidemiological linkage.

\section{Analytical study}

In Bivariate analysis, age of study participants, educational status of mothers/care givers, have or have not medical treatment for measles, contact history with cases and travel history 7-18 days prior onset of illness had p-value less than or equal to 0.25 and these variables were included in multivariable analysis (Table 2).

In Multivariable analysis, age of study participants, contact history with cases $(\mathrm{AOR}=2.78,95 \%$ CI $1.23-$ 8.67) and travel history 7-18 days prior onset of illness $(\mathrm{AOR}=2.53,95 \% \mathrm{CI} 1.31-7.24)$ were significantly associated with measles (Table 2).

\section{Discussion}

In this outbreak investigation, the overall attack rate was $11.8 / 100,000$. This is higher than the study conducted in Somalia region $28.6 / 100,000$ [8], and the investigation conducted in Guji Zone, Oromia region, Ethiopia [17]. This difference might be due to vaccination coverage, $14.8 \%$ and $16 \%$ of measles cases had history of vaccination in Somalia region and Guji Zone, respectively but in this investigation $100 \%$ of measles cases had not vaccination history.

The overall attack of this outbreak investigation is consistent with the investigation conducted in Pakistan which had the overall attack rate 11.3/100,000 [18]. This might be due to vaccination status similarity of measles cases because all cases in Pakistan had no vaccination history.

In this study, about $57.1 \%$ (95\% CI, 42.9-71.4\%) of the cases were females. This is consistent with investigation conducted in Somalia 45.3\% [8] and Pakistan 51\% [18]. This might be due to females are more vulnerable for malnutrition $[4,6]$ because of cultural influence.

In this outbreak investigation, the age specific attack rate $(29.1 / 100,000)$ is higher in the age of $5-14$ years. This is discrepancy with the study conducted in Somali region Ethiopia that showed that the more affected age group were $<1$ year [17]. This might be due to the age group 5-14 years of children had immunization in routine or supplemental immunization activity (SIA) in Somali region. In this study, all age group of the cases had no history of immunization.

The Cumulative CFR rate of this investigation was $2.6 \%$ (95\% CI, 2.5-8.6\%). This is consistent with the studies conducted in Pakistan 7.27\% [6] and Nigeria 3.9\% [19]. 


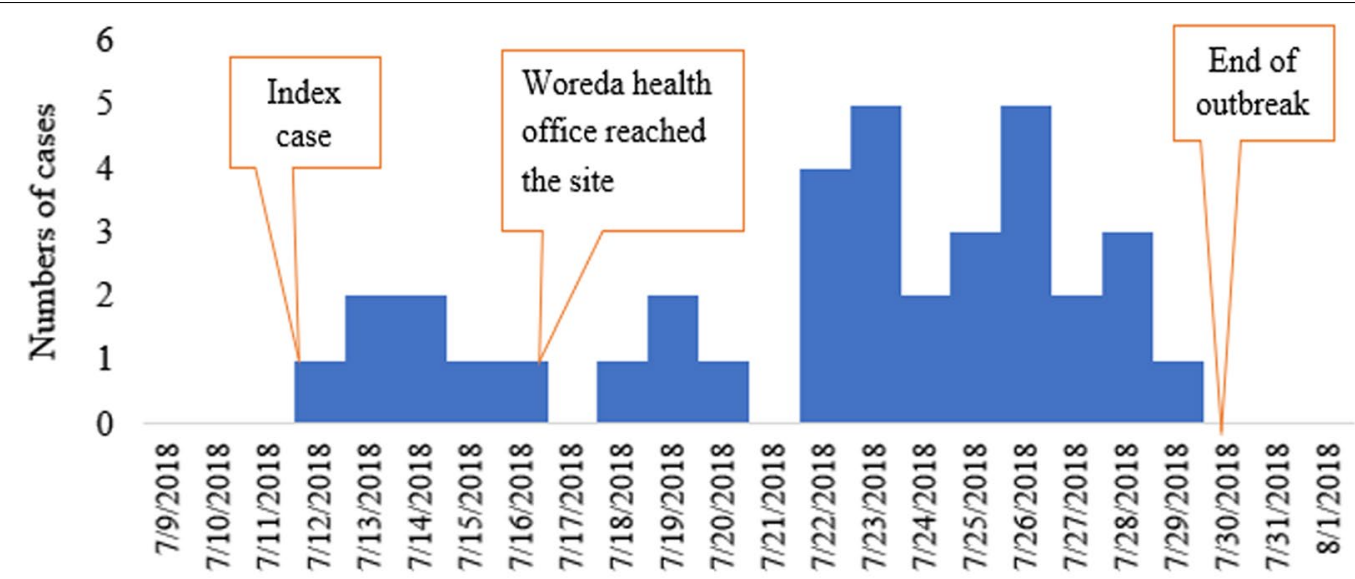

Date of onset

Fig. 1 Epi curve shows distribution measles cases by date of onset of sign and symptom in Artuma Fursi Woreda, Oromia Zone, Northeast Ethiopia, 2018

Table 2 Multivariable analysis of factors associated with measles outbreak in Artuma Fursi Woreda, Oromia Zone, Amhara region, Ethiopia, 2018

\begin{tabular}{|c|c|c|c|c|c|}
\hline \multirow[t]{2}{*}{ Variables } & \multicolumn{2}{|c|}{ Respondent status } & \multirow[t]{2}{*}{ COR $(95 \% \mathrm{Cl})$} & \multirow[t]{2}{*}{ AOR $(95 \% \mathrm{Cl})$} & \multirow[t]{2}{*}{ p-value } \\
\hline & Cases $=38$ & Controls $=152$ & & & \\
\hline \multicolumn{6}{|l|}{ Age in year } \\
\hline$<1$ & 2 & 8 & $9.9(1.01-15.21)$ & $6.42(2.12-10.03)$ & 0.001 \\
\hline $1-4$ & 10 & 12 & $32.07(1.34-46.84)$ & $3.13(1.08-6.41)$ & $<0.0001$ \\
\hline $5-14$ & 24 & 53 & $17.89(8.29-27.31)$ & $3.53(1.52-8.45)$ & 0.002 \\
\hline$\geq 15$ & 2 & 79 & 1 & 1 & 0.001 \\
\hline \multicolumn{6}{|c|}{ Educational status of mothers/care givers } \\
\hline Unable to read and write & 27 & 98 & $1.29(1.01-6.68)$ & $1.90(0.85-4.23)$ & 0.091 \\
\hline $\begin{array}{l}\text { Read and write but has no formal } \\
\text { education }\end{array}$ & 8 & 34 & $1.57(1.14-7.78)$ & $1.4(0.50-5.11)$ & 0.054 \\
\hline Primary & 3 & 20 & 1 & 1 & 0.070 \\
\hline \multicolumn{6}{|l|}{ Do measles have medical treatment } \\
\hline No & 27 & 91 & $1.65(0.72-3.63)$ & $1.45(0.63-4.23)$ & 0.063 \\
\hline Yes & 11 & 61 & 1 & 1 & \\
\hline \multicolumn{6}{|l|}{ Contact with case } \\
\hline Yes & 6 & 41 & $0.51(0.18-3.98)$ & $2.78(1.23-8.67)$ & $<0.0001$ \\
\hline No & 32 & 111 & 1 & 1 & \\
\hline \multicolumn{6}{|c|}{ History travel 7-18 days prior onset of illness } \\
\hline Yes & 15 & 36 & $2.10(1.22-5.71)$ & $2.53(1.31-7.24)$ & $<0.0001$ \\
\hline No & 23 & 116 & 1 & 1 & \\
\hline
\end{tabular}

But this finding is higher than the study conducted in Somalia region (Ethiopia) 1.2\% [8] and Guji Zone, Oromia region (Ethiopia) $0.2 \%$ [17]. This might be due to late outbreak response because the Woreda Health Office gave response after the index case dead.

In this investigation, age is significantly associated with contracting measles. Being age between 5 and 14 years were almost 3.5 times more likely contracting measles than peoples who is age $\geq 5$ years. This is consistent with the investigation conducted in Nigeria which showed that case and death of measles were significantly associated with age [19].

Persons who had contact with measles case were almost 3 times more likely in contracting measles than persons who had not contact with measles case. This is consistent with the study conducted in Zimbabwe [20]. 
In this outbreak investigation, persons who had history of travel 7-18 days prior onset of illness were almost 2.5 times more likely in contracting measles in the study area than those who had not travel history 7-18 days prior to the onset of illness. This is in line with the study conducted in china [21]. The justification of this result might be traveled persons might prone to contracting measles.

\section{Conclusion}

Measles outbreak was occurred at Golbo Arba Keble in Artuma Fursi Woreda revealed that all measles cases not immunized. Age group of 5-14 years had higher AR. All cases were from one gote. Age, contact with cases and having history of travel 7-18 days prior onset of illness were factors for contracting measles It is recommended that early and proper response should be given. People who have travel history should be traced, and community surveillance and outreach vaccination should be strengthened.

\section{Limitation}

The immune status of the controls was not measured. This may lead selection bias. Due to cultural influence, some mothers/care givers might hide some measles cases. Case definition was not laboratory confirmation. Thus, some measle cases might be missed classified.

\section{Abbreviations}

AOR: adjusted odd ratio; AR: attack rate; CFR: case fatality rate; Cl: confidence interval; COR: crude odd ratio.

\section{Acknowledgements}

We would like to acknowledge Bahir Dar University, College of Medicine Health Sciences and Department of Epidemiology and Biostatistics.

Our sincere and deepest gratitude would go to Ethiopian Public health Institute, Oromia Zone Health department and Artuma Fursi Woreda health office. We would also like to extend our thanks to data collectors, supervisors and study participants.

\section{Authors' contributions}

MK wrote study design, data entry, analyzed the data, and drafted paper. SW approved the design and the study. Both authors read and approved the final manuscript.

\section{Funding}

Data collection of this investigation was funded by Ethiopian Public Health Institute. Funding body had not any role in the design of the study, analysis, and interpretation of data and in writing the manuscript.

\section{Availability of data and materials}

The data sets generated during the current study are available from corresponding author on reasonable request.

\section{Ethics approval and consent to participate}

Ethical approval was obtained from Oromia Zone Health department Multi sectorial taskforce. Permission letter was sought from Artuma Fursi Woreda health office. Written and Verbal informed consent was obtained from each participant. The study participants had the right to refuse in the study or withdraw at any time during the interview was respected. The information obtained from the study participant was maintained its confidentiality by not writing name of the study participants on the questionnaire paper. All cases were managed before interviewed.

\section{Consent for publication}

Not applicable.

\section{Competing interests}

The authors declare that they have no competing interests.

\section{Author details}

${ }^{1}$ Aneded Woreda Health Office, East Gojjam, Amhara Region, Ethiopia. ${ }^{2}$ Felege Hiote Specialized Referral Hospital, Bahir Dar, Ethiopia.

Received: 6 Auqust 2019 Accepted: 12 November 2019

Published online: 21 November 2019

\section{References}

1. WHO. www.http///E:/Field2ndsemester/outbreak/disaster/WHO20 _Measles.html. Measles Reviewed on January 2018. Accessed 13 Oct 2018.

2. Pan American Health Organization. 2005 Pan American Sanitary Bureau Root WHO measles elimination field guide, 2nd ed. 2005.

3. WHO. Outbreak investigation guideline. 2013.

4. WHO. Measles facts sheet. Accessed 11 Sept 2018.

5. van den Ent MMVX, Brown DW, Hoekstra EJ, Christie A, Cochi SL. Measles mortality reduction contributes substantially to reduction of allcause mortality among children less than five years of age, 1990-2008. J Infect Dis. 2011;204:S18-23. https://doi.org/10.1093/infdis/jir081.

6. CDC. Measles-horn of Africa, 2010-2011. Accessed 24 Sept. 2018.

7. Poletti P, Parlamento S, Fayyisaa T, Feyyiss R, Lusiani M, Tsegaye A, Segafredo G, Putoto G, Manenti F, Merler S. The hidden burden of measles in Ethiopia: how distance to hospital shapes the disease mortality rate. BMC Med. 2018;16:177. https://doi.org/10.1186/s12916-018-1171-y.

8. Griffiths UK, Mounier-Jack S, Oliveira-Cruz V, Balabanova D, Hanvoravongchai P, Ongolo P. How can measles eradication strengthen health care systems? J Infect Dis. 2011;204:S78-81. https://doi. org/10.1093/infdis/jir090.

9. Castillo-Solorzano C, Marsigli C, Danovaro-Holliday MC, RuizMatus C, Tambini G, Andrus JK. Measles and rubella elimination initiatives in the Americas: lessons learned and best practices. J Infect Dis. 2011;204:279-83. https://doi.org/10.1093/infdis/jir216.

10. Guideline on measles surveillance and outbreak management, 3rd ed. EHNRI, January 2012, Addis Ababa Ethiopia.

11. CSA, Ethiopian Demographic and Health Survey, 2016.

12. Akalu BH. Review on measles situation in Ethiopia; past and present. J Trop Dis. 2015;4:2.

13. Abramovich E, Indenbaum V, Haber M, Amitai Z, Tsifanski E, Farjun S, Sarig A. Measles Outbreak in a Highly Vaccinated Population-Israel, July-August 2017. MMWR Morb Mortal Wkly Rep. 2018;67:2017-9.

14. WHO. Measles 2018. https://www.who.int/news-room/fact-sheets/ detail/measles. Accessed 19 Aug 2018.

15. Artuma Fursi Woreda annual plan, July 2010 Chefa Robite.

16. Yusuf M, Ayalew N. Measles Outbreak Investigation and Response in Jarar Zone of Ethiopian Somali Regional State, Eastern Ethiopia. Int J Microbiol Res. 2017:8(3):86-91.

17. Belda K, Tegegne AA, Mersha AM, Bayenessagne MG, Hussein I, et al. Measles outbreak investigation in Guji Zone of Oromia Region, Ethiopia. Pan Afr Med J. 2017;27(Supp 2):9. https://doi.org/10.11604/pamj. supp.2017.27.2.10705.

18. Saeed A, Butt ZA, Malik T. Investigation of measles outbreak in a district of Balochistan Province, Pakistan. J Ayub Med College Abbottabad. 2015;24(4):900-3.

19. Duru CO, Peterside O, Adeyemi OO. A 5-year review of childhood measles at the Niger Delta University Teaching Hospital, Bayelsa state, Nigeria. J Med Med Sci. 2014;5(4):78-86. https://doi.org/10.14303/ jmms.2014.045.

20. Pomerai KW, Mudyiradima RF, Gombe NT. Measles outbreak investigation in Zaka, Masvingo Province, Zimbabwe, 2010. BMC Res Notes. 2012;5:687. 
21. Wagner AL, Boulton ML, Gillespie BW, Zhang Y, Ding Y, Carlson BF, Luo X, Montgomery JP, Wang $X$. Risk factors for measles among adults in Tianjin, China: who should be controls in a case-control study? PLOS ONE. 2017. https://doi.org/10.1371/journal.pone.0185465.

\section{Publisher's Note}

Springer Nature remains neutral with regard to jurisdictional claims in published maps and institutional affiliations.
Ready to submit your research? Choose BMC and benefit from:

- fast, convenient online submission

- thorough peer review by experienced researchers in your field

- rapid publication on acceptance

- support for research data, including large and complex data types

- gold Open Access which fosters wider collaboration and increased citations

- maximum visibility for your research: over 100M website views per year

At BMC, research is always in progress.

Learn more biomedcentral.com/submissions 